\title{
Total Bakteri dan Kelimpahan Vibrio pada Budidaya Udang Vannamei (Litopenaeus vannamei) Sistem Resirkulasi Tertutup dengan Padat Tebar Berbeda
}

\author{
Bagus Anjasmara ${ }^{a *}$, Pande Gde Sasmita Julyantoroa, Endang Wulandari Suryaningtyas ${ }^{a}$ \\ a Program Studi Manajemen Sumberdaya Perairan, Fakultas Kelautan dan Perikanan, Universitas Udayana, Bukit Jimbaran, Badung, Bali- \\ Indonesia
}

* Penulis koresponden. Tel.: +62-896-665-716-56

Alamat e-mail: bagusanjasmara73@yahoo.co.id

Diterima (received) 8 Agustus 2018; disetujui (accepted) 9 September 2018

\begin{abstract}
Microbial management is one of the succesful keys on shrimp farming, especially with high density culture system. This study aimed to invesigate on the abundance of total bacteria and Vibrios in vannamei shrimp culture using closed recircultion system with different high stocking densities. This study used an experimental method with complete randomized design factorial in a closed recirculation system equipped by bio-filters, protein skimmer, and using artificial feed with addition of probiotic. 9 ponds were used for this experiment including 3 control ponds (K) with $200 \mathrm{ind} / \mathrm{m}^{2}$ stocking density, 3 ponds I (P1) and 3 ponds II (P2) with $500 \mathrm{ind} / \mathrm{m}^{2}$ and $750 \mathrm{ind} / \mathrm{m}^{2}$ stocking density, respectively. Those 3 ponds with similar stocking density represented as three times of replication. After 60 days culture period, the average total bacteria and abundance of Vibrios collected from culture water of K, P1, and P2 ponds were $1,2 \times 10^{4}, 1,6 \times 10^{5}$, and $2,1 \times 10^{4} \mathrm{CFU} / \mathrm{mL}$ of total bacteria and $1,2 \times 10^{3}, 2,8 \times 10^{3}$, and $3,7 \times 10^{2} \mathrm{CFU} / \mathrm{mL}$ of Vibrio. Moreover, at the end of experiment, the average total bacteria and abundance of Vibrio collected from shrimp

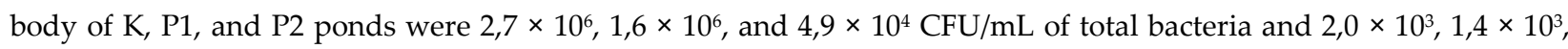
and $8,5 \times 10^{2} \mathrm{CFU} / \mathrm{mL}$ of Vibrio. The statistical test of ANOVA showed that there were not significant differences $(p<0,05)$ of total bacteria and Vibrio abundance both on the culture water and shrimp body between different shrimp stocking densities.
\end{abstract}

Keywords: Microbes; Recirculating Aquaculture System

\begin{abstract}
Abstrak
Manajemen pengelolaan mikroba perairan menjadi salah satu kunci sukses pemeliharaan udang terutama dengan pada penebaran yang tinggi. Tujuan penelitian ini untuk melihat total bakteri dan kelimpahan Vibrio yang tumbuh pada budidaya udang vannamei sistem resirkulasi tertutup dengan padat tebar berbeda. Penelitian ini menggunakan metode eksperimental dengan rancangan acak lengkap faktorial (RALF) dan dilakukan di kolam sistem resirkulasi tertutup yang dilengkapi dengan bio-filter, protein skimmer, dan penambahan probiotik pada pakan serta air budidaya. Penelitian ini menggunakan 9 kolam yaitu 3 kolam Kontrol (K) 200 ekor/m². 3 kolam I (P1) 500 ekor/m² dan 3 kolam II (P2) 750 ekor/m². Pada masing - masing kolam, sampel untuk perhitungan kelimpahan bakteri di ambil dari air dan tubuh udang. Setelah 60 hari periode kultur, rata - rata total bakteri dan kelimpahan Vibrio pada air

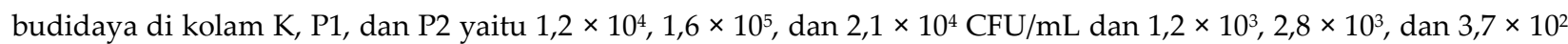
CFU/mL. Pada akhir eksperimen, rata - rata total bakteri dan kelimpahan Vibrio pada tubuh udang di kolam K, P1, dan P2 yaitu $2,7 \times 10^{6}, 1,6 \times 10^{6}$, dan $4,9 \times 10^{4} \mathrm{CFU} / \mathrm{mL}$ dan $2,0 \times 10^{3}, 1,4 \times 10^{3}$, dan $8,5 \times 10^{2} \mathrm{CFU} / \mathrm{mL}$. Uji statistik ANOVA menunjukkan bahwa kelimpahan total dan bakteri baik pada air budidaya maupun tubuh udang tidak berbeda secara signifikan $(\mathrm{p}<0,05)$ pada padat penebaran yang berbeda.
\end{abstract}

Kata Kunci: Mikroba; Resirkulasi 


\section{Pendahuluan}

Udang vannamei (Litopenaeus vannamei) adalah salah satu spesies udang yang saat ini banyak dikembangkan oleh para pembudidaya udang di Indonesia. Udang vannamei merupakan udang introduksi yang resmi diperkenalkan di Indonesia pada tahun 2001 melalui Surat Keputusan (SK) Menteri Kelautan dan Perikanan RI No.41/2001 dengan tujuan meningkatkan produksi udang Indonesia (Subyakto, 2009). Kehadiran varietas udang vannamei ini mampu menopang kebangkitan usaha budidaya udang di Indonesia serta membuat investasi di bidang budidaya udang memiliki potensi yang baik untuk dikembangkan. Peningkatan produksi udang pada kenyataannya tidak diimbangi peningkatan ekspor udang. Permintaan ekspor udang Indonesia mengalami penurunan karena tidak memenuhi standar mutu negara konsumen, diantaranya bebas bakteri patogen, antibiotik, dan pengawet. Sehingga diperlukan suatu sistem budidaya yang bisa memenuhi standar tersebut. sistem intensifikasi untuk meningkatkan produksi umumnya memiliki permasalahan timbulnya penyakit di area budidaya. Penyakit yang ditimbulkan oleh bakteri, virus, dan jamur dapat terjadi apabila terjadi ketidakseimbangan antara inang, patogen, dan lingkungan (Zonneveld et al., 1991).

Manajemen pengelolaan mikroba perairan menjadi salah satu kunci sukses pemeliharaan udang pada tebar tinggi. Salah satu jenis pengelolaan mikroba adalah dengan penerapan aplikasi bakteri probiotik yang mampu memberikan efek menguntungkan kesehatan udang vannamei dengan menggunakan sistem RAS (Recirculating Aquaculture System) yang memanfaatkan kembali air yang sudah digunakan dengan mengalirkan air secara kontinyu untuk selanjutnya air tersebut dikembalikan ke kolam budidaya (Pande et al, 2015). Tujuan penelitian ini adalah untuk melihat pengaruh padat tebar berbeda terhadap total bakteri dan kelimpahan Vibrio pada budidaya udang vannamei sistem resirkulasi tertutup.

\section{Metode Penelitian}

\subsection{Waktu dan Tempat}

Penelitian ini dilaksanakan pada bulan Januari Maret 2018 di tambak udang vannamei yang berlokasi di Gerokgak, Buleleng Bali dan Laboratorium Ilmu Perikanan Fakultas Kelautan dan Perikanan Universitas Udayana Bali. Lokasi tambak udang vannamei tertera pada peta berikut (Gambar 1).

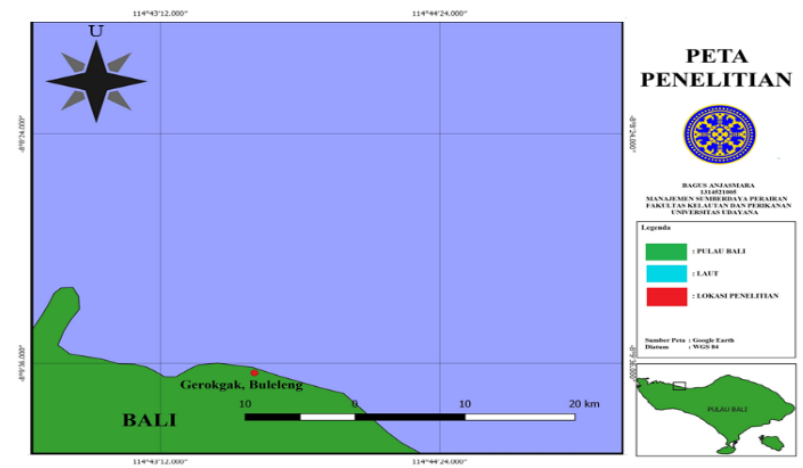

Gambar 1. Lokasi Penelitian

\subsection{Alat dan Bahan}

Alat - alat yang digunakan pada penelitian ini meliputi: erlenmeyer, cawan petri, batang pengaduk, timbangan analitik, sendok, autoklaf, hotplate, magnetic stirrer, mikropipet, mikro tip, vortex, tabung reaksi, inkubator, api bunsen, hocky stick sterril, easy effendorf, dan oven. Sedangkan bahan - bahannya meliputi: udang vannamei, air budidaya, NA, TCBS, aqudes, botol sampel, sarung tangan, alumunium foil, plastik sampel, kapas, spiritus, dan $\mathrm{NaCl}$. Alat - alat yang digunakan pada penelitian ini meliputi: erlenmeyer, cawan petri, batang pengaduk, timbangan analitik, sendok, autoklaf, hotplate, magnetic stirrer, mikropipet, mikro tip, vortex, tabung reaksi, inkubator, api bunsen, hocky stick sterril, easy effendorf, dan oven. Sedangkan bahan bahannya meliputi: udang vannamei, air budidaya, NA, TCBS, aqudes, botol sampel, sarung tangan, alumunium foil, plastik sampel, kapas, spiritus, dan $\mathrm{NaCl}$.

\subsection{Metode Penelitian}

Penelitian ini menggunakan metode eksperimental dengan rancangan acak lengkap faktorial (RALF). Penelitian dilakukan di tambak sistem tertutup yang dilengkapi dengan bio-filter dan protein skimmer. Probiotik ditambahkan ke dalam pakan sebagai perlakuan. Sampel penelitian yang digunakan pada penelitian ini adalah udang vannamei umur 40 hari (berat udang 1 gr). Kolam 
pada penelitian ini memiliki volume air 49.000 liter yang terdiri dari sembilan kolam yaitu :

$\mathrm{K}_{1,2,3}$ : Kolam kontrol dengan kepadatan 200 ekor $/ \mathrm{m}^{2}$. $\mathrm{K}_{2}$ dan $\mathrm{K}_{3}$ merupakan kolam ulangan $\mathrm{K}_{1}$

$\mathrm{P} 11,2,3$ : Kolam perlakuan pertama dengan kepadatan 500 ekor/m². P12 dan P13 merupakan kolam ulangan dari $\mathrm{P} 1_{1}$

P21,2,3: Kolam perlakuan kedua dengan kepadatan 750 ekor/m². P22 dan P2 3 merupakan kolam ulangan dari $\mathrm{P} 21$

Penempatan kolam perlakuan menyesuaikan dengan kondisi di tambak. Masing - masing perlakuan dilakukan pengulangan sebanyak tiga kali (Gambar 2).

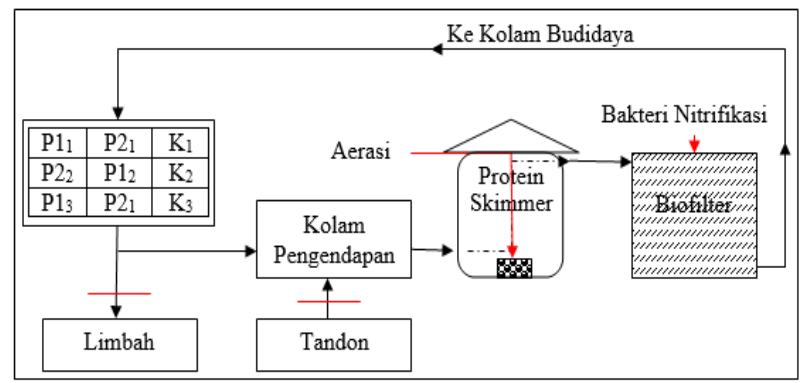

Gambar 2. Alur Resirkulasi Penelitian

Dosis probiotik yang diberikan melalui oral (pakan) dan air budidaya adalah 0.05 ppm. Probiotik pada kolam K diberikan secara oral pada pakan, sedangkan pada P1 dan P2 diberikan melalui air budidaya. Pemeliharaan udang vannamei dilakukan selama 60 hari periode kultur.

\subsection{Analisis Data}

Penyajian data bakteri yang diisolasi dari tubuh udang vannamei dan air budidaya dihubungkan dengan padat penebaran yang berbeda dan penambahan probiotik. Perbedaan antar kolam akan di uji secara statistik menggunakan One Way Anova serta Post Hoc Tukey.

\section{Hasil}

3.1 Total Bakteri dan Kelimpahan Vibrio pada Air Budidaya dan Tubuh Udang

Jumlah total bakteri tertinggi pada air budidaya terdapat di kolam P2 dengan rata - rata 2,1 $\times 10^{5}$ $\mathrm{CFU} / \mathrm{ml}$ dan terendah di kolam $\mathrm{K}$ dengan rata rata $1,2 \times 10^{4} \mathrm{CFU} / \mathrm{ml}$. Sedangkan total bakteri tertinggi pada tubuh udang terdapat di kolam $\mathrm{K}$ dengan rata - rata $2,7 \times 10^{6} \mathrm{CFU} / \mathrm{ml}$ dan terendah di kolam P2 dengan rata - rata 4,9 × 104 CFU/ml. Kelimpahan Vibrio tertinggi pada air budidaya terdapat di kolam P1 dengan rata - rata 2,8 $\times 10^{3}$ $\mathrm{CFU} / \mathrm{ml}$ dan terendah di kolam P2 dengan rata rata $3,7 \times 10^{2} \mathrm{CFU} / \mathrm{ml}$. Sedangkan kelimpahan Vibrio tertinggi pada tubuh udang terdapat di kolam $\mathrm{K}$ dengan rata - rata 2,0 $\times 10^{3} \mathrm{CFU} / \mathrm{ml}$ dan terendah di kolam P2 dengan rata - rata 8,5 × $10^{2}$ $\mathrm{CFU} / \mathrm{ml}$. Berdasarkan uji statistik dengan analisis ANOVA tidak berbeda signifikan $(p>0,05)$ antar semua kolam (Tabel 1).

Tabel 1

Total Bakteri dan Kelimpahan Vibrio pada Air Budidaya dan Tubuh Udang

\begin{tabular}{|c|c|c|c|c|c|}
\hline Kolam & Minggu Ke- & $\begin{array}{c}\text { Total Bakteri } \\
\text { pada Air } \\
(\mathrm{CFU} / \mathrm{ml}) \\
\end{array}$ & $\begin{array}{c}\text { Total Bakteri } \\
\text { pada Udang } \\
(\mathrm{CFU} / \mathrm{ml})\end{array}$ & $\begin{array}{c}\text { Total Vibrio } \\
\text { pada Air } \\
(\mathrm{CFU} / \mathrm{ml})\end{array}$ & $\begin{array}{c}\text { Total Vibrio } \\
\text { pada Udang } \\
(\mathrm{CFU} / \mathrm{ml})\end{array}$ \\
\hline \multirow{3}{*}{ K } & 1 & $2.1 \times 10^{4}$ & $2.3 \times 10^{5}$ & $6.0 \times 10^{2 *}$ & $0.4 \times 10^{3}$ \\
\hline & 2 & $7,9 \times 10^{3}$ & $6,9 \times 10^{6^{*}}$ & $8,7 \times 10^{2}$ & $6,0 \times 10^{3}$ \\
\hline & 3 & $9,0 \times 10^{3}$ & $1,0 \times 10^{6^{*}}$ & $2,4 \times 10^{3}$ & $5,2 \times 10^{3}$ \\
\hline \multirow[t]{2}{*}{ Rata-rata } & & $1,2 \times 10^{4}$ & $2,7 \times 10^{6}$ & $1,2 \times 10^{3}$ & $2,0 \times 10^{3}$ \\
\hline & 1 & $3,8 \times 10^{3}$ & $1,5 \times 10^{5}$ & $1,7 \times 10^{3}$ & $4,7 \times 10^{2}$ \\
\hline \multirow[t]{2}{*}{ P1 } & 2 & $4,7 \times 10^{5 *}$ & $4,0 \times 10^{6^{*}}$ & $5,7 \times 10^{3}$ & $1,7 \times 10^{3}$ \\
\hline & 3 & $5,1 \times 10^{3}$ & $7,4 \times 10^{5^{*}}$ & $1,0 \times 10^{3}$ & $2,2 \times 10^{3}$ \\
\hline \multirow[t]{2}{*}{ Rata-rata } & & $1,6 \times 10^{5}$ & $1,6 \times 10^{6}$ & $2,8 \times 10^{3}$ & $1,4 \times 10^{3}$ \\
\hline & 1 & $3,0 \times 10^{3}$ & $8,1 \times 10^{4}$ & $3,0 \times 10^{2}$ & $3,0 \times 10^{2}$ \\
\hline \multirow[t]{2}{*}{ P2 } & 2 & $6,4 \times 10^{5^{*}}$ & $2,6 \times 10^{4}$ & $8,0 \times 10^{3}$ & $1,6 \times 10^{3}$ \\
\hline & 3 & $6,1 \times 10^{3}$ & $4,2 \times 10^{4}$ & $3,0 \times 10^{3}$ & $6,5 \times 10^{2}$ \\
\hline Rata-rata & & $2,1 \times 10^{5}$ & $4,9 \times 10^{4}$ & $3,7 \times 10^{2}$ & $8,5 \times 10^{2}$ \\
\hline
\end{tabular}

${ }^{*}$ Notasi statistik menunjukkan perbedaan yang tidak signifikan 
Tabel 2

Perbandingan Kelimpahan Vibrio dan Total Bakteri pada Air Budidaya dan Tubuh Udang

\begin{tabular}{ccccccc}
\hline Kolam & \multicolumn{2}{c}{$\begin{array}{c}\text { Kelimpahan Vibrio } \\
(\text { CFU/ml })\end{array}$} & \multicolumn{2}{c}{$\begin{array}{c}\text { Total Bakteri } \\
(\text { CFU/ml })\end{array}$} & $\begin{array}{c}\text { Persentase } \\
\text { TV/TB Air } \\
(\%)\end{array}$ & $\begin{array}{c}\text { Persentase } \\
\text { TV/TB Udang } \\
(\%)\end{array}$ \\
\hline K & $1,2 \times 10^{3}$ & $2,0 \times 10^{3}$ & $1,2 \times 10^{4}$ & $2,7 \times 10^{6}$ & 10,21 & 0,07 \\
P1 & $2,8 \times 10^{3}$ & $1,4 \times 10^{3}$ & $1,6 \times 10^{5}$ & $1,6 \times 10^{6}$ & 1,68 & 0,08 \\
P2 & $3,7 \times 10^{2}$ & $8,5 \times 10^{2}$ & $2,1 \times 10^{5}$ & $4,9 \times 10^{4}$ & 0,17 & 1,71 \\
\hline
\end{tabular}

\subsection{Perbandingan Kelimpahan Vibrio dan Total Bakteri pada Air Budidaya dan Tubuh Udang}

Perbandingan bakteri pada air budidaya yang tertinggi pada kolam $\mathrm{K}$ dengan rata - rata persentase $10,21 \%$ diikuti oleh kolam P1 dan P2 dengan rata - rata persentase $1,68 \%$ dan $0,17 \%$. Sedangkan pada tubuh udang yang tertinggi pada kolam P2 dengan rata - rata persentase 1,71\% diikuti oleh kolam P1 dan $\mathrm{K}$ dengan rata - rata persentase $0,08 \%$ dan $0,07 \%$ (Tabel 2).

\subsection{Parameter Kualitas Air}

Kisaran rata - rata parameter suhu yaitu 27,5 $27,9^{\circ} \mathrm{C}$. Rata - rata parameter DO yaitu $3,74-4,28$ ppm. Rata - rata parameter $\mathrm{pH}$ yaitu $6,81-6,92$. Rata - rata parameter salinitas yaitu 36,3-36,6 ppt. Rata - rata parameter ammonia rata - yaitu 0,04 $0,05 \mathrm{ppm}$ dan rata - rata parameter nitrit yaitu 0,04 - 0,05 ppm.

Tabel 3

Rata - rata Nilai Parameter Kualitas Air

\begin{tabular}{ccccccc}
\hline Kolam & $\begin{array}{c}\text { Suhu } \\
\left({ }^{\circ} \mathbf{C}\right)\end{array}$ & $\begin{array}{c}\text { DO } \\
(\mathbf{p p m})\end{array}$ & $\mathbf{p H}$ & $\begin{array}{c}\text { Salinitas } \\
(\mathbf{p p t})\end{array}$ & $\begin{array}{c}\mathbf{N H}_{3} \\
(\mathbf{p p m})\end{array}$ & $\begin{array}{c}\mathbf{N O}_{2} \\
(\mathbf{p p m})\end{array}$ \\
\hline $\mathrm{K}$ & 27,5 & 4,28 & 6,81 & 36,6 & 0,05 & 0,05 \\
$\mathrm{P} 1$ & 27,7 & 4,18 & 6,92 & 36,6 & 0,04 & 0,05 \\
$\mathrm{P} 2$ & 27,9 & 3,74 & 6,83 & 36,3 & 0,04 & 0,04 \\
\hline
\end{tabular}

\section{Pembahasan}

\subsection{Total Bakteri dan Kelimpahan Vibrio pada Air Budidaya}

umlah total bakteri tertinggi pada air budidaya di kolam P2 diduga karena padat penebaran yang lebih tinggi $\left(750 \mathrm{ekor} / \mathrm{m}^{2}\right)$ sehingga akumulasi nutrien pada kolam P2 jumlahnya tinggi. Nutrien dibutuhkan oleh bakteri untuk kehidupan dan pertumbuhannya (Waluyo, 2007). Sedangkan jumlah total bakteri tertinggi pada tubuh udang di kolam $\mathrm{K}$ diduga karena padat penebaran $\mathrm{K}$ yang paling rendah dan adanya penambahan probiotik pada pakan secara oral yang terus - menerus. Bakteri yang dicampurkan pada pakan yang tidak termakan akan terlepas dari air budidaya (Wulandari, 2013) dan bakteri yang terdapat dalam air budidaya dapat menempel pada pakan dan eksoskeleton udang. Bakteri yang masuk ke pencernaan udang melalui enzim yang dihasilkan bakteri pengurai yang ikut termakan dapat meningkatkan keseimbangan mikroba dalam usus dan juga berperan dalam memproduksi enzim pencernaan eksogen protease, amilase dan lipase (Siti, 2011).

Kelimpahan Vibrio pada air budidaya dan tubuh udang pada masing-masing kolam masih dalam batas normal pemeliharaan udang vannnamei. Hal ini sesuai dengan pernyataan Taslihan et al (2004), ambang batas maksimal keberadaan bakteri Vibrio sp. dalam air adalah $10^{4}$ $\mathrm{CFU} / \mathrm{ml}$ dan jika ambang batas ini dilampaui maka kematian massal udang budidaya dalam tambak dapat terjadi. Jika populasi Vibrio tinggi dan tidak dapat ditekan akan menyebabkan kondisi yang beresiko. Sesuai dengan pernyataan Supito et al (2008) yang mengemukakan bahwa dominansi dan kelimpahan bakteri Vibrio yang tidak stabil pada tambak menunjukkan kondisi yang beresiko terhadap masalah kesehatan udang. Keberadaan probiotik (Bacillus megaterium) juga berperan dalam menekan jumlah kelimpahan Vibrio pada air budidaya. Isramilda (2007) menjelaskan bahwa hasil karakteristik zat antimikroba yang dihasilkan Bacillus megaterium berupa bakteriosin berupa senyawa polipeptida yang disintesis melalui ribosom. Sedangkan pada tubuh udang, keberadaan probiotik (Bacillus megaterium) dalam saluran pencernaan dapat meningkatkan keseimbangan mikroba dalam saluran pencernaan sehingga meningkatkan penyerapan pakan serta menekan jumlah patogen dalam saluran pencernaan (Praditia, 2009). Namun, berdasarkan uji statistik dengan analisis ANOVA dan 
dilanjutkan dengan Post Hoc Tukey tidak berbeda signifikan $(p<0,05)$ antar semua kolam.

\subsection{Perbandingan Total Bakteri dan Kelimpahan Vibrio pada Tubuh Udang}

Hasil total bakteri selalu lebih tinggi dibandingkan dengan kelimpahan Vibrio pada air budidaya dan tubuh udang. Hal ini diduga karena bakteri probiotik (Bacillus megaterium) yang diberikan pada air budidaya dan pakan berhasil memberikan efek yang positif dalam menekan populasi Vibrio. Susana (2017) yang mengemukakan bakteri Bacillus sp. yang diuji dengan bakteri patogen (Vibrio algynolyticus, Aeromonas hydrophila dan Pseudomonas sp) membentuk hambatan, bakteri tersebut menghasilkan produk antibiotik. Balca'zar dan Rojas-Luna (2007) menunjukan bahwa Bacillus menghasilkan senyawa antimikroba terhadap jenis-jenis Vibrio patogen yang meliputi Vibrio alginolyticus, Vibrio parahaemolyticus dan Vibrio harveyi. Sedangkan pada tubuh udang, bakteri probiotik di duga melakukan kompetisi ruang pada eksoskeleton dan saluran pencernaan udang. Bakteri probiotik memproduksi senyawa - senyawa anti mikroba patogen atau melalui kompetisi nutrisi dan tempat pelekatan di dinding intestinum, merubah metabolisme bakteri dengan meningkatkan atau menurunkan aktivitas enzim, dan menstimulasi imunitas melalui peningkatan kadar antibodi atau aktivitas makrofag (Nopitawati, 2010).

Persentase perbandingan bakteri yang tertinggi pada air budidaya terdapat di kolam $\mathrm{K}$ dan pada tubuh udang di kolam P2 dikarenakan total bakteri lebih sedikit dibandingkan dengan kolam lainnya. Persentase perbandingan bakteri di atas $1 \%$ sudah termasuk rentan dalam budidaya udang vannamei. Hal ini sesuai dengan pernyataan Tashlihan et al (2004), bahwa persentase perbandingan bakteri Vibrio dan bakteri umum diperairan yang aman yaitu maksimal $1 \%$ untuk mencegah kematian massal pada udang akibat penyakit vibriosis.

\subsection{Pengaruh Kualitas Air Terhadap Keberhasilan Sistem Budidaya Tertutup}

Hasil rata - rata parameter suhu masih sesuai dengan nilai optimum dan toleransi untuk kehidupan udang vannamei. Haliman, et al (2005) menjelaskan suhu optimum pertumbuhan udang antara $26-32^{\circ} \mathrm{C}$. Hasil rata - rata parameter DO berada dalam nilai optimum untuk budidaya udang vannamei. Nilai DO optimum pada budidaya udang vannamei yaitu $>3 \mathrm{mg} / \mathrm{L}$ (SNI, 2006). Hasil DO pada masing-masing kolam mengindikasikan adanya bakteri pada air budidaya yang turut memanfaatkan oksigen. Beristain et al., (2005) yang menyatakan bakteri aerobik akan menggunakan oksigen dalam media budidaya untuk proses dekomposisi bahan organik.

Hasil rata - rata parameter $\mathrm{pH}$ yaitu 6,81 - 6,92 dimana hasil tersebut hampir mendekati nilai optimum terhadap budidaya udang vannamei. Nilai $\mathrm{pH}$ optimum pada budidaya udang vannamei yaitu $7,0-8,5$ (BBPBAP, 2017). Perubahan $\mathrm{pH}$ sangat mempengaruhi stabilitas mikroba di kolam pemeliharaan, karena $\mathrm{pH}$ juga merupakan faktor yang menyebabkan stres pada beberapa organisme budidaya termasuk bakteri probiotik yang ditambahkan pada air budidaya dan pakan. Fluktuasi $\mathrm{pH}$ yang cenderung turun juga terlihat pada setiap masing-masing perlakuan dikarenakan padat tebar yang tinggi dan penambahan bakteri yang juga berperan dalam mengakomodasi nilai $\mathrm{pH}$, akan tetapi penurunannya tidak terjadi secara spontan dan tidak mempengaruhi produksi udang. Menurut Wayan et al (2010), kondisi pH 4 - 6 tidak mempengaruhi kelulushidupan kehidupan, tetapi hanya menghambat pertumbuhan. Namun demikian, nilai $\mathrm{pH}$ pada masing - masing kolam masih dalam batas toleransi pemeliharaan udang vannamei yaitu $\mathrm{pH} 6$ - 9 .

Hasil rata - rata parameter salinitas yaitu 36,3 36,6 ppt. Nilai optimum salinitas pada budidaya udang vannamei yaitu 15 - 25 ppt (SNI, 2006). Namun demikian, nilai tersebut masih dalam batas toleransi pemeliharaan udang vannamei yaitu salinitas 5-40 ppt.

Hasil rata - rata parameter amonia berada dalam nilai optimm pemeliharaan budidaya udang vannamei. Menurut Adiwijaya (2003), nilai ambang batas kandungan amonia pada budidaya udang vannamei berkisar antara $<0,1$ ppm. Amonia merupakan produk akhir dari hasil metabolisme protein. Menurut Crab et al (2007) bahwa amonia bersifat toksik terhadap udang pada tingkat konsentrasi yang tinggi, batas maksimum konsentrasi amonia diperairan adalah 1,5 ppm. Tetapi pemberian bakteri probiotik mampu menurunkan kadar konsentrasi amonia 
(Wulandari, 2013). Menurut Devaraja et al. (2013) bahwa Bacillus sp. mampu menurunkan kandungan amonia perairan.

Hasil rata - rata parameter berada dalam nilai optimum. Adiwijaya et al (2003) mengemukakan bahwa kandungan nitrit yang dapat ditoleransi oleh udang vannamei berkisar $<0,05 \mathrm{ppm}$. Nitrit pada darah udang menghalangi gas oksigen oleh hemocyanin, dengan demikian mengurangi nafsu makan dan kesehatan udang karena gangguan transfer oksigen dalam darah (Rahmat, 2011).

\section{Simpulan}

Kelimpahan Vibrio pada air budidaya dan tubuh udang masih dalam batas normal pemeliharaan udang vannnamei dan berdasarkan uji statistik dengan analisis ANOVA dan dilanjutkan dengan Post Hoc Tukey tidak berbeda signifikan $(p>0,05)$ antar semua kolam.

\section{Ucapan Terimakasih}

Allah SWT atas karunianya. Kedua orang tua dan adik - adik penulis yang selalu memberi dukungan serta doa. Petani budidaya udang vannamei. Best-Partner penelitian ini, tim bakteri, dan JJS yang telah membantu.

\section{Daftar Pustaka}

Adiwijaya, D., Sapto, P. R., Sutikno, E., Sugeng., \& Subiyanto. (2003). Budidaya Udang Vaname (Litopenaeus vannamei) Sistem Tertutup yang Ramah Lingkungan. Departemen Kelautan dan Perikanan. Jepara, Indonesia: Balai Besar Pengembangan Budidaya Air Payau Jepara.

Balcazar, J. L., deBlas, I., Ruizzarzuela, I., Cunningham, D., Vandrell, D., \& Muzquiz, J. L. (2007). A review: The Role of Prebiotics in Aquaculture. Veterinary Mincrobiology, 114 (2007), 173-178.

BBPBAP Jepara. (2017). Budidaya Udang Vannamei (Litopenaeus vannamei). Jepara, Indonesia: Balai Besar Pengembangan Budidaya Air Payau, Kementerian Kelautan dan Perikanan Republik Indonesia.

Beristain, B. T. (2005). Organic matter decomposition in simulated aquaculture ponds. Thesis. Wageningen, Netherlands: Fish Culture and Fisheries Group, Wageningen Institute of Animal Science, Wageningen University.

Crab, R., Y. Avnimelech., Defoirdt, T., Bossier, P., \& Verstraete, W. (2007). Nitrogen Removal Techniques in Aquaculture for Sustainable Production. Aquaculture. 270, 1-14.
Devaraja, T., Banerjee, S., Yusoff, F., Shariff, M., \& Khatoon, H. (2013). A holistic approach for selection of Bacillus sp. as a bioremediator for shrimp postlarvae culture. Turkish Journal of Biology. 37, 92 100.

Haliman, R. W. \& Adijaya, D. (2005). Udang Vannamei. Jakarta, Indonesia: Penebar Swadaya.

Isramilda. (2007). Karakterisasi zat antimikrob penghambat pertumbuhan Vibrio harveyi dan E. Coli dari Bacillus sp. asal tambak udang. Tesis. Bogor, Indonesia: Sekolah Pascasarjana, Institut Pertanian Bogor.

Nopitawati, T. (2010). Seleksi Bakteri Probiotik dari Saluran Pencernaan untuk Meningkatkan Kinerja Pertumbuhan Udang Vaname Litopenaeus vannamei. Tesis. Bogor, Indonesia: Program Studi Ilmu Akuakultur, Sekolah Pascasarjana, Institut Pertanian Bogor.

Pande. G. S. J., Fatin, M. I. L., Ace, V. B. F, Uday, K., Yufeng, N., Peter, B., \& Defroidt, T. 2015. Isolation of AHL-degrading Bacteria From Micro-algal Cultures and Their Impact on Algal Growth and on Virulence of Vibrio campbellii to Prawn Larvae. Applied Microbiology and Biotechnology, 99(24), 10805-10813.

Praditia, F. P. (2009). Pengaruh Pemberian Bakteri Probiotik Melaluix Pakan terhadap Pertumbuhan dan Kelangsungan Hidup Udang Windu Penaeus monodon. Skripsi. Bogor, Indonesia: Departemen Budidaya Perairan, Fakultas Perikanan dan Ilmu Kelautan, Institut Pertanian Bogor.

Siti, A. (2011). Kualitas Lingkungan dan Aktivitas Enzim Pencernaan Udang Vannamei (Litopenaeus vannamei) Pada Berbagai Konsentrasi Probiotik Bioremidiasi Bacillus sp. Jurnal Fish scientiae, 1(2), 161-178.

Subyakto, S. (2009). Budidaya Udang Vannnamei (Litopenaeus vannamei) Semi Intensif Dengan Metode Resirkulasi Tertutup Untuk MenghindariSerangan Virus. Berkala Ilmiah Perikanan, 3(1), 1-7.

Supito, D. A. Maskar, J., \& Damang, S. (2008). Teknik Budidaya Udang Windu Intensif Dengan Green Water System Melalui Penggunaan Pupuk Nitrat Dan Penambahan Sumber Karbon. Media Budidaya Air Payau, 7, 38-53.

Susana, M. (2017). Isolasi Dan Karakteristik Bakteri Heterotrofik Pada Perairan Laut Kawasan Pemukiman Dan Perairan Bersalinitas Rendah Di Kelurahan Purnama Dumai Provinsi Riau. Skripsi. Pekanbaru, Indoneia: Universitas Riau.

Taslihan, A., Ani, W., Retna, H., \& Astuti, S. M. (2004). Pengendalian Penyakit Pada Budidaya Ikan Air Payau. Jepara, Indonesia: Balai Besar Budidaya Air Payau Jepara.

Waluyo, L. (2007). Mikrobiologi Umum Edisi Revisi. Malang, Indonesia: UMM Press.

Wayan, A. E., Kamaludin, A., Januar, P. M., Chaerudin, K. (2010). Budidaya Udang Putih (Litopenaeus vannamei). Jakarta, Indonesia : CV. Mulia Indah. 
Wulandari, D. (2013). Pengaruh Pemberian Probiotik terhadap Penurunan Bahan Organik dalam Air Media Pertumbuhan udang vannamei (Litopenaeus vannamei) di BBPBAP Jepara. Skripsi. Semarang, Indonesia: IKIP PGRI Semarang.

Zonneveld, N., Huisman, E. A., \& Boon, J. H. (1991). Budidaya Ikan. Jakarta, Indonesia: Gramedia Jakarta. 